\section{Hematopoietic Growth Factors and In Vitro Growth of Human Acute Myeloblastic Leukemia}

\author{
Bob Löwenberg, Ruud Delwel, and IVo Touw
}

\section{HEMATOPOIETIC STEM CELLS: IN VITRO ASSAYS AND REGULATORY FACTORS}

The production of mature blood cells is finely regulated, so that the homeostasis can be maintained and cell production be adapted to the specific needs of particular blood cell compartments (e.g., granulocytes during infection). A complex regulatory network of positive and negative signals and cellular interactions serves the hematopoietic system to fulfill this role. In vitro colony assays are powerful tools for studies that aim at the recognition of hematopoietic progenitor cells of distinct differentiation pathways and at different levels of maturation. These assays have also been used to define the complex role of hematopoietic growth factors in normal hematopoiesis. The same technology is currently being applied for elucidating growth factor responses of neoplastic clonogenic cells in hematopoietic disease.

An in vitro colony assay for primitive multilineage hematopoietic precursor cells of both rodents and humans with the capacity to form granulocytic cells, macrophages, erythrocytes, megakaryocytes, collectively designated as CFUGEMM, has been developed. ${ }^{1-3}$ Somewhat more mature progenitor cells that are committed to one henatopoietic lineage can be assayed in vitro as erythroid burst-forming units (BFU. E) ${ }^{4,5}$ erythroid colony-forming units (CFU-E), ${ }^{6}$ granulocyte/ monocyte CFU (CFU-GM), ${ }^{7.8}$ granulocyte CFU (CFU-G), monocyte CFU (CFU-M), eosinophil CFU (CFU-Eo), or megakaryocyte CFU (CFU-Mega). ${ }^{9}$ Several regulatory molecules that induce colony formation from those precursor cells have been isolated following molecular cloning.

In acute myeloid leukcmia (AML), a transformed malignant precursor cell arises that is unable to generate terminally differentiated cells. This neoplastic cell population apparently escapes normal maturation impulses and expands aproportionally in marrow and blood.

The technology of in vitro colony formation has been applied to examine the proliferation and differentiation abilities of leukemic progenitor cells. In this review we discuss our understanding of leukemic blood cell formation in human AML, mainly based on the study of in vitro growth.

\section{RECOMBINANT HEMATOPOIETIC COLONY STIMULATING FACTORS}

The hematopoietic colony stimulating factors and their target precursor cells are listed in Table 1. These glycoproteins regulate the proliferation and outgrowth of different hematopoietic progenitors and frequently have a role in stimulating the metabolic and functional activities of the mature cell types as well.

\section{A. Human Multilineage Colony Stimulating Factor (Multi-CSF) or Interleukin-3 (IL-3)}

Murine IL-3, ${ }^{38-40}$ also termed multi-CSF, ${ }^{41}$ mast cell growth factor, ${ }^{41}$ or stem cell activating factor, ${ }^{42}$ is a stimulator of the proliferation of mouse in vivo multipotential stem cells (CFUs) ${ }^{39.41}$ as well as the in vitro CFU-GEMM. ${ }^{4 !}$ It has been suggested that murine IL-3 is also involved in the self-replication of pluripotent stem cells. ${ }^{40,43,44}$ The human homologue of multiCSF/IL-3 has been cloned, ${ }^{10,11}$ and was shown to stimulate the in vitro proliferation of normal bone marrow CFU-GEMM, BFU-E, and CFU-Eo. ${ }^{12}$ A direct stimulating effect of IL-3 upon myeloid progenitors was not apparent in vitro when auxiliary cells had been removed from hematopoietic progenitors before culture. ${ }^{12}$ IL-3 improves the in vitro survival of CFU-G. ${ }^{31}$

\section{B. GM-CSF}

Granulocyte macrophage colony stimulating factor (GMCSF) has effects on the function of granulocytes ${ }^{22.45-47}$ and stimulates the proliferation of CFU-GEMM, BFU-E, and CFUEo in normal marrow. ${ }^{18-22,24,48}$ Human GM-CSF cDNA transferred into $\mathrm{COS}$ cells produces a glycoprotein with a molecular weight of 19,000 to $22,000^{22,24}$ and into Escherichia coli a nonglycosylated molecule with a molecular weight of $16,000 .^{23}$ Radioiodinated GM-CSF has been used to characterize membrane receptors on normal cells. ${ }^{49-51}$ High-affinity (kDa $20 \mathrm{pM}$ to $1 \mathrm{nM}$ ) receptors for GM-CSF are abundantly expressed onnormal neutrophils and eosinophils (500 to 4000 sites per cell).

\section{G-CSF and M-CSF}

Complementary DNA of the gene encoding for human GCSF has been cloned and expressed in E. coli. ${ }^{29,30} \mathrm{G}-\mathrm{CSF}$ (recombinant) has a molecular weight of $18,800 \mathrm{Da}$. G-CSF stimulates granulocytic colonies from normal human marrow. It does not induce eosinophilic colony formation in vitro.

cDNA encoding for human M-CSF, following expression, yields a mature protein of mol wt 26,000 to $45,000 \mathrm{Da}$ depending on differences of posttranscriptional processing. ${ }^{32,33}$

\footnotetext{
B. Löwenberg received a M.D. degree from the State University in Groningen in The Netherlands and a Ph.D. degree from Erasmus University in Rotterdam in The Netherlands. Dr. Lowenberg is currently the Research Director at the Dr. Daniel den Hoed Cancer Center in Rotterdam in The Netherlands. I. P. Touw received a Ph. D. degree from Eramus University in Rotterdam in The Netherlands. Dr. Touw is currently with the Department of Hematology at the Dr. Daniel den Hoed Cancer Center in Rotterdam in The Netherlands.
} 


\section{Table 1}

Human Hematopoletic Growth Factors

\begin{tabular}{|c|c|c|c|c|c|c|c|}
\hline \multirow[b]{2}{*}{ Acronym } & \multirow[b]{2}{*}{$\begin{array}{c}\text { Protein size } \\
\text { (kDa) }\end{array}$} & \multicolumn{2}{|c|}{ Cellular sources } & \multicolumn{4}{|c|}{ Hematopoietic progenitor cell targets } \\
\hline & & Cell type & $\begin{array}{l}\text { Release activated } \\
\text { by }\end{array}$ & Normal & Ref. & Lenkemia & Ref. \\
\hline IL-3 & $14-28$ & T cells & Mitogens & $\begin{array}{l}\text { CFU-GEMM } \\
\text { BFU-e } \\
\text { CFU-Eo }\end{array}$ & $10-12$ & AML-CFU & $13-17$ \\
\hline GM-CSF & $14-35$ & $\begin{array}{l}\text { T cells } \\
\text { Endothelial } \\
\text { cells } \\
\text { Fibroblasts }\end{array}$ & $\begin{array}{l}\text { Mitogens } \\
\text { TNF, IL-1 } \\
\text { TNF, IL-1 }\end{array}$ & $\begin{array}{l}\text { CFU-GEMM } \\
\text { BFU-e } \\
\text { CFU-Eo }\end{array}$ & $18-24$ & AML-CFU & $14-17,25-28$ \\
\hline G-CSF & $18-22$ & $\begin{array}{l}\text { Monocytes } \\
\text { Fibroblasts } \\
\text { Endothelial } \\
\text { cells }\end{array}$ & TNF, IL-1 & CFU-G & $29-31$ & AML-CFU & $14-17,28$ \\
\hline M-CSF & $\begin{array}{c}35-45 \\
(\times 2) \\
18-26\end{array}$ & $\begin{array}{l}\text { Monocytes } \\
\text { Fibroblasts } \\
\text { Endothelial } \\
\text { cells }\end{array}$ & TPA, $\gamma$ IFN & CFU-M & 32,33 & $\begin{array}{l}\text { AML-CFU } \\
\text { (rare) }\end{array}$ & $14,16,34$ \\
\hline EPO & 36 & $\begin{array}{l}\text { Kidney } \\
\text { Liver }\end{array}$ & $\begin{array}{l}\text { Hypoxia } \\
\text { Low oxygen }\end{array}$ & $\begin{array}{l}\text { BFU-e } \\
\text { CFU-e }\end{array}$ & 35,36 & $\begin{array}{l}\text { AML-CFU } \\
\text { (M-6 type) }\end{array}$ & 14,37 \\
\hline
\end{tabular}

The biological activity on normal human hematopoietic cells is only scarcely defined. On the other hand, human M-CSF is a potent inducer of murine macrophage colonies in vitro.

\section{Erythropoietin}

Erythropoietin was purified following molecular cloning and expression in mammalian cells. ${ }^{35,36}$ Recombinant erythropoietin (mol wt 36,000 glycosylated) stimulates BFU-E and CFU-E in vitro.

\section{HEMATOPOIESIS IN AML}

The malignantly transformed cell population expands progressively when clinical AML evolves. In the marrow of AML patients immature cells, i.e., myeloblasts, predominate. Concomitantly, normal hematopoiesis is suppressed, presumably by physical displacement of the normal stem cells by leukemic cells or inhibitory humoral factors (such as acidic isoferritins) ${ }^{\mathbf{5 2}}$ produced by the leukemic cells, leading to the characteristic anemia, thrombocytopenia, and leukopenia.

Although AML is the result of clonal expansion of a single cell, ${ }^{53}$ the resulting leukemic cell population is biologically heterogeneous as is evident from morphological, ${ }^{3} \mathrm{H}$-thymidine labeling, ${ }^{54}$ immunological, cytogenetic, and colony culture studies. For instance, a small population of proliferating cells expressing self-renewal capacities can be identified among the AML cell mass in colony assays. ${ }^{55}$

\section{A. Techniques for AML Colony Growth}

In the initial attempts to grow leukemic colonies, normal leukocyte feeder cells were added to an agar underlayer as a source of stimulating factors, ${ }^{56,57}$ and AML blast cells were plated in a second layer on top of the underlayer. The appearance of leukemia-derived clones in these cultures has been confirmed by cytogenetic analysis. ${ }^{58}$ Other colony stimulating materials that were applied for in vitro growth of normal CFUGM have also been employed for growing AML clonogenic cells, e.g., conditioned media from cell lines, ${ }^{59,60}$ human placental-conditioned medium (HPCM), ${ }^{61}$ or phytohemagglutinin (PHA)-leukocyte-conditioned medium. ${ }^{62,63}$

While these methods efficiently induce normal myeloid colony formation, they are often insufficient to permit the outgrowth of AML colonies. In some cases, no or only single cells survive in the dish at the end of culture, indicating that no proliferation had occurred at all. ${ }^{64-66}$ Frequently, small (less than 20 cells) or somewhat larger clusters (less than 40 cells) are produced during culture. Using standard culture techniques, the nongrowing and small cluster-forming groups of patients account for the majority (60 to $70 \%$ ) of the newly diagnosed cases of AML. ${ }^{66,67}$ Seven-day colonies are composed of morphologically identifiable blast cells carrying cytogenetic AML markers.

Attempts have been made to develop more efficient AML culture methods. Exposure of the cells to PHA during a 15-h preincubation in suspension and subsequent culturing in a soft agar dish with a leukocyte feeder allowed for the formation of significant numbers of AML colonies of more than 50 cells in the majority of patients with AML. ${ }^{70}$ In subsequent modifications of the technique, PHA was added directly to one-stage cultures that contained irradiated leukocytes in the agar underlayer and the AML target cells in a liquid overlayer, ${ }^{68,69}$ or PHA and HPCM in combination have been used as additions 
to agar cultures. ${ }^{71}$ Others have employed PHA-leukocyte-conditioned medium as a stimulus in methylcellulose. ${ }^{62,72,73}$ These modified cultures are permissive to AML colony formation in 80 to $90 \%$ of cases. ${ }^{55}$ However, the disadvantage of this type of assay is that the quantitative analysis of colony formation of leukemic cells can be hampered to a certain extent due to agglutination by PHA. ${ }^{71}$

Thus the original colony culture techniques were based on the use of crude stimulating materials for growing AML-clonogenic cells, e.g., leukocyte feeder cells or conditioned media from cell lines, human placenta, or PHA-activated peripheral blood mononuclear cells. ${ }^{55}$ It has been shown that particularly T-lymphocytes and monocytes are the active subsets among the leukocyte feeder cells. ${ }^{74}$

Since the availability of pure growth factors, it has recently become possible to (1) understand the exact role of these hormones, either as individual or as combined activities in controlling the proliferation and differentiation of human AML cells and to identify possible abnormalities of AML growth in vitro and (2) standardize culture techniques for reproducible application in human AML, that is, with optimal concentrations of stimulators and without inhibitors. Therefore, in vitro studies are now undertaken to elucidate the complex system of growth factor regulation of human AML precursors. In this respect, the completely serum-free culture method for human AML cells, which was designed recently, appears a useful addition to the experimental arsenal. ${ }^{75}$

\section{B. Cell-Cell and Stroma-Cell Contact}

Several investigators ${ }^{70.71}$ have noted that the application of a liquid phase to the culture of AML cells results in more efficient cell growth and, conversely, that growth was inhibited in increasing concentrations of immobilizing methylcellulose. ${ }^{68,69}$ The fact that the cells could easily form small aggregates from which colony formation was initiated suggested that cell to cell contact may provide signals essential to AML cell growth in vitro. ${ }^{70}$ The importance of cell-cell interactions is further supported by enhanced DNA synthesis that was seen when cell proliferative activity of AML blasts was evaluated in direct cell contact facilitating conditions in comparison to cell contact prohibitive circumstances. ${ }^{76}$ These comparisons were made under identical conditions, and an enhanced proliferative rate was positively related to the intensity of cell contact. Increased CSF concentrations in culture could not circumvent the dependence on cell-cell contact. Which membrane structures are involved in enhancement of AML proliferation in vitro is presently unknown. An analysis dealing with a possible role of the leukocyte function antigens (LFA), i.e., LFA1, Mac1, p150-95, did not provide evidence to indicate that these surface molecules are directly involved in the upregulation of AML growth. ${ }^{76}$

The importance of the marrow microenvironment for hematopoietic function is evident from in vitro and in vivo studies in rodents, but the role of the marrow stroma with respect to growth of human leukemia is largely elusive at the present time. It has been found that loss of leukemic proliferating cells occurs following cultivation upon stromal layers and that this loss is selective in comparison to normal hematopoietic stem cells. ${ }^{77}$ In CML, blast precursor cells were defective in their capacity to adhere to cultured stromal cells when compared with their normal marrow counterparts, and it was argued that alterations in cell surface properties of the cells may determine modified migration and maturation. ${ }^{78}$ The adhesive properties of the progenitor cells of human acute leukemia have not yet been examined in any reasonable detail.

\section{Cellular Heterogeneity}

The heterogeneous cellular composition of human AML may be regarded as a hierarchy of subpopulations of cells of different maturation stages. ${ }^{55,79}$ This concept is supported by immunological data that indicate that among AML blasts the in vitro colony forming cells (AML-CFU) carry immature surface phenotypes, while the immunophenotypically more mature cells among the leukemia lack proliferative (i.e., colony forming) abilities ${ }^{80}$ Upon proliferation in vitro, colony forming cells give rise to maturing progeny, but maturation is incomplete. ${ }^{63.81}$ Apparently the dynamics and negative relationships between proliferation and differentiation events characteristic of the normal hematopoietic system have to a certain extent been retained in human AML. It is difficult to determine the in vivo significance of AML-CFU. In vitro observations support the idea that they function to maintain and expand the malignancy and indeed act as progenitor cells: (1) they have capacities for self-renewal, ${ }^{82-84}$ and (2) as normal hematopoietic precursors, they have the capacity not only to proliferate, but also to undergo some further differentiation in vitro. ${ }^{63.81 .85 .86}$

Immunologic analysis has shown that the phenotypes of AML-CFU vary markedly among patients with AML. In certain cases, AML-CFU share immunologic features with CFUGEMM cells, while in other instances AML-CFU express surface antigen combinations typical of committed granulocyte/ macrophage progenitors in normal bone marrow (CFU-GM). ${ }^{s 5}$ Thus it has been appreciated that the immunological phenotypes of AML progenitors and particular types of normal hematopoietic precursors are largely similar. However, detailed surface marker studies have revealed that discrepancies between the immunologic surface phenotypes of AML-CFU and the majority normal marrow progenitors may exist. In one study that considered not only the presence or absence of antigenic determinants, but also marker density at the cell surface, differences between the immunophenotypes of AML-CFU from most of the normal hematopoietic progenitor cells were recognized. ${ }^{87-89}$ Thus, frequently, the surface immunophenotypes of AML-CFU and the normal hematopoietic precursors are dissimilar. Crucial in these studies was that a combination of surface markers was selected that identified a constant surface 
profile for CFU-GEMM, BFU-e, as well as day 7 CFU-GM and 14 CFU-GM and thus permitted the recognition of phenotypes of AML-CFU at variance with these normal progenitors. Probably, these dominant progenitor phenotypes in AML reflect those of infrequent, although essentially normal, hematopoietic precursors that have expanded selectively in AML as a consequence of the abnormality of maturation.

\section{The Role of Colony Stimulating Factors in AML}

Have AML cells become independent of CSFs, so that they will expand in a truly autonomous fashion? The answer to this question is probably no. In most cases of clinical AML, the cells show normal susceptibility to growth factor stimulation. IL-3 and GM-CSF, at usual concentrations, each as individual factors, induce colony formation in vitro, ${ }^{15,27.28} \mathrm{stim}$ ulate DNA synthesis, ${ }^{14,16}$ and enhance the survival of AML progenitors in vitro. ${ }^{15} \mathrm{GM}-\mathrm{CSF}$ has also been shown to support the self-renewal of AML precursors. ${ }^{26}$ In addition to IL-3 and GM-CSF, G-CSF is successful in inducing AMP cell growth in culture at approximately similar frequency. Often, the same leukemias are susceptible to multiple CSFs. Each of these three CSFs as single factors is able to generate significant proliferation in vitro. Infrequently, M-CSF induces AML growth in culture, and erythropoietin has occasionally been reported to act as a growth factor in human AML, i.e., in cases of erythroleukemia (M6). ${ }^{14,37}$ The fact that in certain cases of AML proliferation can be maximally stimulated in the presence of an impure PHA-leukocyte-conditioned medium leaves the possibility open that yet other soluble growth factors operate in AML.

The CSFs affect overlapping stages of the hematopoietic pathways and thus, to a significant extent, exert stimulating effects upon the same target cells. As yet, it remains unclear why it would be useful for the progenitor cells to be stimulable by more than one factor. Obviously, insight into the cooperative interactions between these molecules in controlling human AML growth is of particular interest.

In tritiated thymidine uptake assays it appeared that the responsiveness of AML cells to IL-3 parallels the response to GM-CSF. ${ }^{14,16}$ This suggests that IL-3- and GM-CSF-responsive subpopulations of AML precursors to a certain extent overlap. Also it has become evident that usually IL-3 and GMCSF do not produce additive proliferative effects, again suggesting that the two CSFs act mainly upon the same AML precursor cell subpopulation. In contrast, G-CSF produces additive growth-potentiating effects in certain cases of AML, when supplemented to cultures with IL-3 or GM-CSF. In colony culture, IL-3 has been shown to elevate colony numbers in a majority of AML cases when supplemented along with $G$ CSF or GM-CSF to the cultures, ${ }^{15}$ but the total colony numbers formed in response to the combinations of CSFs were less than the sum of the individual effects. ${ }^{28}$ Therefore, most likely, the AML cell mass contains a spectrum of subsets of precursors with variable growth factor reactivities that can be recruited into cell proliferation, depending on the exact combination of growth factors supplied. These AML cells may represent the neoplastic counterparts of normal marrow progenitors at more or less primitive stages of maturation exhibiting specific CSF requirements.

From dose-effect studies with CSFs, a marked patient-topatient variation with respect to growth factor responsiveness of AML cell proliferation has become apparent (Table 2). Thus different patterns of response can be distinguished among clinical cases, of AML. For instance, AML cell cycle activation can be achieved with any one of the four CSFs in certain cases of AML, whereas the cells of other patients respond to three or two factors only, or sometimes even to only one of the CSFs. These variations may provide indicators of classifying patients with biologically different disease and may prove to be of prognostic value. Generally, the categories of growth factor reactivity do not correlate with morphological classification of human AML, except in the rare cases of erythroleukemia that appeared especially sensitive to erythropoietin. AML progenitor immunophenotypes established as a parameter of precursor cell maturation did not show a relationship with in vitro growth factor dependence either. ${ }^{14}$

- Table 2

\section{Frequency of Recombinant Hematopoietic Growth Factors Acting As Stimuli of Human AML Growth In Vitro}

\begin{tabular}{|c|c|c|c|c|}
\hline IL-3 & GM-CSF & G-CSF & M-CSF & Assay \\
\hline- & $32 / 48$ & $28 / 48$ & $0 / 48$ & Colony formation \\
\hline - & $16 / 20$ & - & - & Colony formation \\
\hline $8 / 9$ & $9 / 9$ & $5 / 9$ & - & Colony formation \\
\hline $19 / 25$ & $16 / 25$ & $13 / 25$ & $4 / 25$ & $\begin{array}{l}\text { DNA synthesis } \\
\text { (serum-free) }\end{array}$ \\
\hline $7 / 20$ & $9 / 20$ & $6 / 20$ & $2 / 20$ & $\begin{array}{l}\text { Colony formation } \\
\text { (serum-free) }\end{array}$ \\
\hline
\end{tabular}

Note: Ratios indicate quotients of positive responses and total number of cases examined.

The biological basis of the heterogeneity of growth factor responsiveness in clinical AML is not clear. The abilities of the AML blasts to react to certain CSFs and not to others could reflect the physiological diversity of normal hematopoietic progenitors with respect to their susceptibility to the hematopoietic growth factors. In this sense, the diversity of response could indicate the selective increase of certain precursors that have accumulated as a result of the differentiation arrest. An alternative hypothesis to explain these phenomena of growth factor responses is that variations of cell growth are expressions of the transformed status of the cells and that asynchronous maturation is associated with abnormalities (e.g., a loss) of growth factor regulation. As our understanding of specific differences 
of growth factor regulation between discrete precursor cell stages even in normal hematopoietis is only beginning to emerge, it is impossible to distinguish between these two explanations at the present time.

Which features of AML growth determine the imbalance of growth between AML and the normal hematopoietic tissue, and why does AML at a certain stage outgrow the normal tissue? Evidence indicating that the overgrowth of AML in normal marrow is caused by specific regulatory abnormalities is still lacking. Preferential growth of AML cells could result from an extraordinary susceptibility to one of the hematopoietic growth factors, for example, due to an overexpression of receptors or their permanent activation by structural receptor abnormalities. Generally, the susceptibility of human AML to IL-3, GM-CSF, or G-CSF $2,24,26$ and the density of GM-CSF receptors upon AML blasts are in the same order as for normal cells. ${ }^{49-51}$ For instance, GM-CSF acts optimally at concentrations of 1 to $5 \mathrm{ng} / \mathrm{ml}$ ( 40 to $200 \mathrm{U} / \mathrm{ml}, 60$ to $300 \mathrm{pM}$ ). ${ }^{22.24}$ AML blasts express comparatively low levels ( 8 to 100 sites per cell) of GM-CSF receptors. ${ }^{49,51}$

Another possible way of conferring a growth advantage upon AML cells would be the creation of an autocrine loop of stimulation. RNA message of GM-CSF has been demonstrated in the blasts of certain cases of $\mathrm{AML}^{90.91}$ Colony stimulating activity was demonstrated in supernatants conditioned by AML cells. This activity could be neutralized by an anti-GM-CSF antibody. ${ }^{92}$ These data provided evidence for the autocrine production and secretion of GM-CSF in human AML. Indeed, in certain cases, AML cells will form colonies in vitro in the absence of any exogenously supplemented growth stimulus. It remains questionable as to whether or not GM-CSF production and GM-CSF response truly reside in one and the same cell that both belong to the leukemic clone.

Release of CSFs from monocytes, ${ }^{93}$ fibroblasts, ${ }^{94}$ and endothelial cells ${ }^{95-97}$ is normally induced by specific stimuli, e.g., tumor necrosis factor (TNF) ${ }^{97-99}$ or interleukin-1 (IL-1). ${ }^{94,95,100}$ A question that is not definitely settled is whether the synthesis and release of CSFs by AML cells is controlled by physiological regulators or if it is constitutive. It has become apparent that synthesis of GM-CSF by AML blasts can be induced following exposure of the cells to interleukin-1 alpha (IL-1 alpha) or IL-1 beta, ${ }^{101}$ and that in certain cases spontaneous AML cell proliferation in vitro can be switched off not only by anti-GM-CSF antibody, but also with neutralizing anti-IL1 antibody. As a matter of fact, GM-CSF elaboration from AML blasts and the resulting proliferative activity may be governed by similar inducers (e.g., IL-1) as that in normal cell types. Thus, CSF release from AML blasts may be under regulatory control rather than constitutive.

One could argue that a CSF-mediated autocrine process of stimulation of AML blasts is not a malignant feature of the cells, i.e., associated with their transformed status. Autocrinemediated growth in hematopoietis is not unusual and does not necessarily represent neoplastic alteration. For example, the production of IL- 2 by T-lymphocytes and the stimulability of the same cells by this factor, or the synthesis of M-CSF by monocytes are physiological phenomena. ${ }^{93}$ Normal hematopoietic blast cells have not been critically examined for this particular feature.

Taken together, no experimental evidence has been obtained to explain why AML growth gains a selective advantage over normal hematopoietis. Obviously, aspects of cell-cell interactions and the susceptibility of progenitor cells to recombinant inhibiting factors have not yet been critically evaluated in the context of the recombinant hematopoietic growth factors.

\section{E. Maturation}

Whereas the hematopoietic growth factors are highly active in triggering cell proliferation, they appear usually incapable of inducing maturation in human AML blasts. Surface markers indicative of progressive myeloid maturation did not appear as the result of incubation of the cells with IL-3, GM-CSF, or GCSF. ${ }^{15,16,26}$ Only in rare instances do IL-3, GM-CSF, G-CSF, or M-CSF bring about morphological alterations that are indicative of monocytic or granulocytic maturation. ${ }^{16,34}$ Thus, although the cells express surface receptors for these factors and their cell cycle status can be activated by these molecules, they are unable to proceed along the maturation pathway. These observations suggest an abnormality in the intracellular machinery that follows growth factor receptor ligand binding. The inefficiency of these factors to induce maturation in AML cells was only slightly improved when the factors were presented to the cells in vitro as complete cocktails of IL-3, GM-CSF, G-CSF, M-CSF, and EPO.

Why are AML cells incompetent to mature to terminally differentiated granulocytic cells when exposed to the appropriate growth factors? Obviously, the answer to this question is fundamental with respect to our understanding of neoplastic growth. As the cells are intact at the level of ligand receptor binding, one may assume that the defect preventing proper maturation resides further downstream in the cell and involves the signal transduction route. Why a normal hematopoietic progenitor cell that responds to growth factor activation is capable of mounting a sequential series of maturation events and why the leukemic cell is incapable of eliciting a similar response are unresolved and remain a main target of future research. 


\section{REFERENCES}

1. Johnson, G. R. and Metcalf, D., Pure and mixed erythroid colony formation in vitro stimulated by splecn conditioncd medium with no detectable erythropoietin, Proc. Natl. Acad. Sci. U.S.A., 74, 3879, 1977.

2. Fauser, A. A. and Messner, H. A., Identification of megakaryocytes, macrophages, and eosinophils in colonies of human bone marrow containing neutrophilic granulocytes and erythroblasts, Blood, 53, 1023, 1979.

3. Messner, H. A., Izaguirre, C. A., and Jamal, N., Identification of T lymphocytes in human mixed hemopoietic colonies, Blood, 58, 402, 1981.

4. Axelrod, A. A., McLeod, D. L., Shreeve, M. M., and Heath, D. S., Properties of cells that produce erythrocytic colonies in vitro, in Hemopoiesis in Culture, Robinson, W. A., Ed., U.S. Government Printing Office, Washington, D.C., 1974, 226.

5. Gregory, C. J., Erythropoietin sensitivity as a differentiation marker in the hemopoietic system: studies of three erythropoietic colony responses in culture, J. Cell Physiol., 89, 289, 1976.

6. Stephenson, J. R., Axelrod, A. A., McLeod, D. L., and Shreeve, M. M., Induction of colonies of hemoglobin-synthesizing cells by erythropoietin in vitro, Proc. Natl. Acad. Sci. U.S.A., 68, 1542, 1971.

7. Bradley, T. R. and Metcalf D., The growth of mouse bone marrow cells in vitro, Austr. J. Exp. Biol. Med. Sci., 44, 287, 1966.

8. Pluznick, D. H. and Sachs, L., The cloning of normal "mast" cells in tissue culture, J. Cell Physiol., 66, 319, 1965.

9. Metcalf, D., MacDonald, H. R., Odartchenko, N., and Sordat, B., Growth of mouse megakaryocyte colonies in vitro, Proc. Natl. Acad. Sci. U.S.A., 72, 1744, 1975.

10. Dorssers, L., Burger, H., Bot, F., Delwel, R., Geurts van Kessel, A. H. M., Löwenberg, B., and Wagemaker, G., Characterization of a human multilineage colony stimulating factor cDNA clone identified by a conserved noncoding sequence in mouse interleukin-3, Gene, $55,115,1987$.

11. Yang, Y. C., Clarletta, A. B., Temple, P. A., Chung, M. P., Kovacic, S., Witek-Gianotti, J. S., Leary, A. C., Kriz, R., Donahue, R. E., Wong, G. G., and Clark, S. C., Human IL-3 (multiCSF): identification by expansion cloning of a novel hematopoietic growth factor related to murined IL-3, Cell, 47, 3, 1986.

12. Bot, F. J., Dorssers, L., Wagemaker, G., and Löwenberg, B., Stimulating spectrum of human recombinant multi-CSF (IL-3) on human marrow precursors: importance of accessory cells, Blood, 71, $1609,1988$.

13. Delwel, R., Dorssers, L., Touw, I., Wagemaker, G., and Löwenberg, B., Human recombinant multilineage colony stimulating factor (interleukin 3): stimulator of acute myeloid progenitor cells in vitro, Blood, 70, 333, 1987.

14. Delwel, R., Salem, M., Pellens, G., Dorssers, L., Wagemaker, G., Clark, S., and Löwenberg, B., Growth regulation of human acute myeloid leukemia: effects of five recombinant hematopoietic factors, in a serum free cultures system, Blood, 72, 1944, 1988.

15. Vellenga, E., Ostapovicz, D., O'Rourke, B., and Grifinn, J. D., Effects of recombinant IL-3, GM-CSF, and G-CSF on proliferation of leukemic clonogenic cells in short- and long-term cultures, Leukemia, $1,584,1987$.

16. Löwenberg, B., Salem, M., and Delwel, R., Effects of recombinant multi-CSF, GM-CSF, G-CSF and M-CSF on the proliferation and maturation of human AML in vitro, Blood Cells, 14, 539, 1988.

17. Miyauchi, J., Kelleher, C. A., Yang, Y., Wong, G. G., Clark, S. C., Minden, M. D., Minkin, S., and McCullouch, E. A., The effects of three recombinant growth factors, IL-3, GM-CSF, and G$\mathrm{CSF}$, on the blast cells of acute myeloid leukemia maintained in short term culture, Blood, 70, 657, 1987.

18. Lee, F., Yokota, T., Otsuka, T., Gemmell, L., Larson, N., Luh, J., Arai, K. I., and Rennick, D., Isolation of cDNA for a human granulocyte-macrophage colony stimulating factor by functional expression in mammalian cells, Proc. Natl. Acad. Sci. U.S.A., 82, $4360,1985$.

19. Wong, G. G., Witek, J. S., Temple, P. A., Wilkins, K. M., Leary, A. C., Luxenberg, D. P., Jones, S. S., Brown, E. L., Kay, R. M., Orr, E. C., Shoemaker, C., Golde, D. W., Kaufman, R. J., Hewick, R. M., Wang, E. A., and Clark, S. C., Human GM-CSF: molecular cloning of the complementary DNA and purification of the natural and recombinant proteins, Science, 228, 810, 1985.

20. Sieff, C. A., Emerson, S. G., Donahue, R. E., Nathan, D. G., Wang, E. A., Wong, G. G., and Clark, S. C., Human recombinant granulocyte-macrophage colony stimulating factor: a multi-lineage hematopoietin, Science, 230, 1171, 1985.

21. Donahue, R. E., Emerson, S. G., Wang, E. A., Wong, G. G., Clark, S. C., and Nathan, D. G., Demonstration of burst-promoting activity of recombinant GM-CSF on circulating erythroid progenitors using an assay involving the delayed addition of erythropoietin, Blood, $66,1479,1985$.

22. Metcalf, D., Begley, C. G., Johnson, G. R., Nicola, N. A., Vadas, M. A., Lopez, A. F., Williamson, D. J., Wong, G. G., Clark, S. C., and Wang, E. A., Biologic properties in vitro of a recombinant human granulocyte-macrophage colony stimulating factor, Blood, 67, 37, 1986 .

23. Burgess, A. W., Begley, C. G., Johnson, G. R., Lopez, A. F., Williamson, D. J., Mermod, J. J., Simpson, R. J., Schmitz, A., and DeLamarter, J. F., Purification and properties of bacterially synthesized human granulocyte-macrophage colony stimulating factor, Blood, 69, 43, 1987.

24. Tomonago, M., Golde, D. W., and Gasson, J. C., Biosynthetic (recombinant) human GM-CSF: effect on normal bone marrow and leukemia cell lines, Blood, 67, 31, 1986

25. Grifmin, J. D., Young, D., Herrmann, F., Wiper, D., Wagner, K., and Sabbath, K. D., Effects of recombinant human GM-CSF on proliferation of clonogenic cells in acute myeloblastic leukemia, Blood, $67,1448,1986$.

26. Hoang, T., Nara, N., Wong, G., Clark, S., Minden, M. D., and McCulloch, E. A., Effects of recombinant GM-CSF on the blast cells of acute myeloid leukemia, Blood, 68, 313, 1986.

27. Vellenga, E., Delwel, H. R., Touw, I. P., and Lowenberg, B., Patterns of acute myeloid leukemia colony growth in response to recombinant granulocyte-macrophage colony-stimulating factor (rGMCSF), Exp. Hematol., 15, 652, 1987.

28. Vellenga, E., Young, D. C., Wagner, K., Wiper, D., Ostapovicz, and Grifnn, J. D., The effects of GM-CSF and G-CSF in promoting growth of clonogenic cells in acute myeloblastic leukemia, Blood, 69 , $1771,1987$.

29. Souza, L., Boone, T. C., Gabrilove, J., Lai, P. H., Zsebo, K. M., Murdock, D. C., Chazin, V. R., Bruszewski, J., Lu, H., Chen, K. K., Barendt, J., Platzer, E., Moore, M. A. S., Mertelsmann, R., and Welte, K., Recombinant human granulocyte colony-stimulating factor: effects on normal and leukemic myeloid cells, Science, $232,61,1986$.

30. Nagata, S., Tsuchiya, M., Asano, S., Kaziro, Y., Yamazaki, T., Yamamoto, O., Hirata, Y., Kubota, N., Obeda, M., Nomura, H., and Ono, M., Molecular cloning and expression of cDNA for human granulocyte colony-stimulating factor, Nature, 319, 415, 1986.

31. Bot, F. J., van Eijk, L., Schipper, P., and Löwenberg, B., Effects of interleukin-3 on granulocytic colony forming cells in human bone marrow, Blood, 75, 1157, 1989.

32. Kawasaki, E. S., Ladner, M. B., Wang, A. M., van Arsdell, J., Warren, M. K., Coyne, M. Y., Schweickart, V. L., Lee, M. T., Wilson, K. J., Boosman, A., Stanley, E. R., Ralph, P., and Mark, 
D. F., Molecular cloning of a complementary DNA encoding human macrophage specific colony-stimulating factor (CSF-1), Science, 230, 291, 1985.

33. Wong, G. G., Temple, P. A., Leary, A. C., Witek-Giannotti, J. S., Yang, Y. C., Ciarletta, A. B., Chung, M., Murtha, P., Kriz, R., Kaufman, R. J., Ferenz, C. R., Sibley, B. S., Turner, K. J., Herwich, R. M., Clark, S. C., Yanai, N., Yokota, H., Yamata, M., Saito, M., Motoyoshi, K., and Takaku, F., Human CSF-1: molecular cloning and expression of $4 \mathrm{~kb} c D N A$ encoding the human urinary protein, Science, 235, 1504, 1987.

34. Salem, M., Delwel, R., Mahmoud, L. A., Clark, S., Elbasousy, E. M., and Löwenberg, B., Maturation of human acute myeloid leukemia in vitro: the response of five recombinant haemahopoietic factors in a serum free system, Br. J. Haematol., 71, 363, 1989.

35. Liu, F. K., Suggs, S., Liu, L. H., Browne, J. K., Smalling, R., Egrie, J. L., Chen, K. K., Fox, G. M., Martin, F., Stabinsky, Z., Badrawi, S. M., Lai, P. H., and Goldwasser, E., Cloning and expression of the human erythropoietin gene, Proc. Natl. Acad. Sci. U.S.A., 82, 7580, 1985.

36. Jacobs, K., Shoemaker, C., Rudersdorf, R., Neill, S. D., Kaufman, R. J., Mufson, A., Seehra, J., Jones, S. S., Hewick, R., Fritsch, E. F., Kawakita, M., Shimizu, T., and Myake, T., Isolation and characterization of genomic and cDNA clones of human erythropoietin, Nature, 313, 806, 1985.

37. Tomonaga, M., Jinnai, I., Tagawa, M., Amenomori, T., Nishino, K., Yao, E., Nonaka, H., Kuriyama, K., Yoshida, Y., Matsuo, T., Ichimaru, M., and Suematsu, T., Leukemic blast cell colony formation in semisolid culture with erythropoietin: a case report of poorly differentiated erythroid leukemia, Blood, 69, 546, 1987.

38. Thle, J. N., Keller, J., Henderson, L., Klein, F., and Palaszynski, E., Procedures for the purification of interleukin-3 to homogeneity, $J$. Immunol., 129, 2431, 1982.

39. Hapel, A. J., Fung, M. C., Johnson, R. M., Young, I. G., Johnson, G., and Metcalf, D., Biologic properties of molecular cloned and expressed murine interleukin-3, Blood, 65, 1453, 1985.

40. Fung, M. L., Hapel, A. J., Ymer, S., Cohen, D. R., Johnson, R. N., Campbell, H. D., and Young, 1. G., Molecular cloning of cDNA for mouse interleukin-3, Nature, 307, 233, 1984.

41. Metcalf, D., The Hematopoietic Colony Stimulating Factors, Elsevier, New York, 1984.

42. Wagemaker, G., Van Bekkum, I., and Löwenberg, B., Bone Marrow Transplantation, Marcel Dekker, New York, 1985.

43. Garland, J. M. and Crompton, S., A preliminary report: preparations containing interleukin 3 (IL-3) promote proliferation of multipotential stem cells (CFU-s) in the mouse, Exp. Hematol., 11, 757, 1983.

44. Stanley, E. R., Bartocci, A., Patinkin, D., Rosendaal, M., and Bradley, T. R., Regulation of very primitive multipotent hemopoietic cells by hemopoietin-1, Cell, 45, 667, 1986.

45. Arnaout, M. A., Wang, E. A., Clark, S. C., and Sieff, C. A., Human recombinant granulocyte-macrophage colony stimulating factor increases cell-to-cell adhesion and surface expression of adhesion promoting surface glycoproteins on mature granulocytes, J. Clin. Invest., 78, 597, 1986.

46. Weishart, R. H., Kwan, L., Golde, D. W., and Gasson, J. C., Human GM-CSF primes neutrophils for enhanced oxidative metabolism in response to the major physiological chemo-attractants, Blood, 69, $18,1987$.

47. Gasson, J. C., Weisbart, R. H., Kaufman, S. E., Clark, S. C., Hewick, R. M., Wong, G. G., and Golde, D. W., Purified human granulocyte-macrophage colony stimulating factor: direct action on neutrophils, Science, 226, 1339, 1984.

48. Metcalf, D., The molecular biology and functions of the granulocytemacrophage colony stimulating factors, Blood, 67, 257, 1980.

49. DiPersio, J. F. et al., Properties of the human GM-CSF receptor on normal and leukemic cells, Blood. 68, 164a, 1986.
50. Park, L. S., Friend, D., Gillis, S., and Urdal, D. L., Characterization of the cell surface receptor for human granulocyte/macrophage colony stimulating factor receptor, J. Exp. Med., 164, 251, 1986.

51. Kelleher, C. A., Wong, G. C., Clark, S. C., Schendel, P. F., Minden, M. D., and McCulloch, E. A., Binding of iodinated recombinant human GM-CSF to the blast cells of acute myeloblastic leukemia. Leukemia, 2, 211, 1988.

52. Broxmeyer, H. E., Bognacki, J., Dorner, M. H., and de Sousa, M., The identification of leukemia-associated inhibiting activity (LIA) as acidic isoferritins: a regulatory role for acidic isoferritins in the production of granulocytes and macrophages, J. Exp. Med., 153, 1426, 1981 .

53. Fialkow, P. J., Singer, J. W., Adamson, J. W., Vaidya, K., Dow, L. W., Ochs, J., and Moohr, J. W., Acute nonlymphocytic leukemia: heterogeneity of stem cell origin, Blood, 57, 1068, 1981.

54. Clarkson, B., Fried, J., Strife, A., Sakai, Y., Ota, K., and Ohkita, T., Studies of cellular proliferation in human leukemia. III. Behavior of leukemic cells in three adults with acute leukemia given continuous infusions of ${ }^{3} \mathrm{H}$-thymidine for 8 or 10 days, Cancer, 25, 1237, 1970.

55. Grifiñn, J. D. and Löwenberg, B., Clonogenic cells in acute myeloblastic leukemia, Blood, 68, 1185, 1986.

56. Pike, B. L. and Robinson, W. A., Human bone marrow colony growth in agar gel, J. Cell Physiol., 76, 77, 1970.

57. Robinson, W. A., Kurnick, I. E., and Pike, B. L., Colony growth of human leukemic peripheral blood cells in vitro, Blood, 38, 500, 1971.

58. Moore, M. A. S. and Metcalf, D., Cytogenetic analysis of human acute and chronic myeloid leukemic cells cloned in agar culture, Int. J. Cancer, 11, 143, 1973.

59. Hoang, T. and McCulloch, E. A., Production of leukemic blast growth factor by a human bladder carcinoma cell line, Blood, 66, 748, 1985 .

60. Bowman, G., Goldberg, J., Gottlieb, A. J., Preisler, H. D., Azarnia, N., Priore, R. L., Brennan, J. K., Vogler, W. R., Winton, E. F., Miller, K. B., and Grunwald, H., The clonogenic assay as a reproducible in vitro system to study predictive parameters of treatment outcome in acute non-lymphoblastic leukemia, Am. J. Hemat., 15, $227,1983$.

61. Francis, G. E., Berney, J. J., Tuma, G. A., Wing, M. A., and Hoffbrand, A. V., Divergent sensitivities of leukemic cells to human placental conditioned medium and leukocyte feeder layers. Leuk. Res. 4, 531, 1978.

62. Buick, R. N., Till, J. E., and McCulloch, E. A., Colony assay for proliferative blast cells circulating in myeloblastic leukaemia, Lancet, $1,862,1977$.

63. Marie, J. P., Izaguirre, C. A., Civin, C. I., Mirro, J. H., and McCulloch, E. A., Granulopoietic differentiation in AML blasts in culture, Blood, 58, 670, 1981.

64. Moore, M. A. S., Spitzer, G., Williams, N., Metcalf, D., and Buckley, J., Agar culture studies in 127 cases of untreated acute leukemia: the prognostic value of reclassification of leukemia according to in vitro growth characteristics, Blood, 44, 1, 1974.

65. Bull, J. M., Duttera, M. J., Stashick, E. D., Nortup, J., Henderson, E., and Carbone, P. P., Serial in vitro marrow culture in acute myelocytic leukemia, Blood. 42. 679. 1973.

66. Spitzer, G., Dicke, K. A., Gehan, E. A., Smith, T., McCredie, K. B., Barlogie, B., and Freireich, E. J., A simplified in vitro classification for prognosis in adult acute leukemia: the application of in vitro results in remission-predictive models, Blood, 48, 795, 1976.

67. Moore, M. A. S., Prediction of relapse and remission in AML by marrow culture criteria, Blood Cells. 2, 109, 1976.

68. Löwenberg, B. and Hagemeijer, A., Colony formation of human acute myeloid leukemia cells in vitro, in Advances in Comparative Leukemia Research, Bentvelzen. P. . Hilgers, I., and Yon, D. S., Eds., 
Elsevier/North Holland, Amsterdam, 1977, 274.

69. Löwenberg, B., Swart, K., and Hagemeijer, A., PHA-induced colony formation in acute nonlymphocytic and chronic myeloid leukemia, Leuk. Res., 4, 143, 1980.

70. Dicke, K. A., Spitzer, G., and Ahearn, M. J., Colony formation in vitro by leukaemic cells in acute myelogenous leukaemia with phytohaemagglutinin as stimulating factor, Nature, 259, 129, 1976.

71. Dicke, K. A., Tindle, S. E., Davis, F. M., Jasgannath, S., Tucker, S., Lilien, M., van Leeuwen, P., Verma, D. A., and Vellekoop, L., Leukemic cell colony formation in soft agar by bone marrow cells and peripheral blood cells from untreated acute leukemia patients, Exp. Haematol., 11, 341, 1983

72. Marie, J. P., Zittoun, R., Thevenin, D., Mathieu, M., and Perrot, J. Y., PHA-induced blast colonies and kinetic parameters in acute myeloid leukemia, Leuk. Res., 6, 63, 1982.

73. Minden, M. D., Buick, R. N., and MeCulloch, E. A., Separation of blast cell and T-lymphocyte progenitors in the blood of patients with acute myeloblastic leukemia, Blood, 54, 186, 1979.

74. Swart, K. and Löwenberg, B., Feeder cell requirements of acute leukemia colony growth in PHA supplemented cultures, Cancer Res., 44, 657, 1984.

75. Salem, M., Delwel, R., Touw, I., Mahmoud, L., and Löwenberg, B., Human AML colony growth in serum-free culture, Leuk. Res., 12, 157,1988 .

76. Pulsoni, A., Delwel, R., Salem, M., Touw, I., and Löwenberg, B., Cell to cell contact enhances the proliferation of acute myeloid leukemia (AML) cells in vitro without an apparent role of adhesion glycoproteins LFA-1, Mac-1 and P150-95, Leuk. Res., 13, 883, 1989.

77. Gordon, M. Y., Dowding, C. R., Riley, G. P., Goldman, J. M., and Greaves, M. F., Altered adhesive interactions with marrow stroma of hematopoietic progenitor cells in chronic myeloid leukemia, Nature, $328,342,1987$.

78. Gordon, M. Y., Adhesive properties of hematopoietic stem cells, $\mathrm{Br}$. J. Haematol., 68, 149, 1988.

79. Wouters, R. and Löwenberg, B., On the maturation order of AML cells: a distinction on the basis of self-renewal properties and immunologic phenotypes, Blood, 63, 684, 1984.

80. Löwenberg, B. and Bauman, J. J. G., Further results in understanding the subpopulation structure in AML: clonogenic cells and their progeny identified by differentiation markers, Blood, 66, 1225, 1985.

81. Touw, I. and Löwenberg, B., Variable differentiation of human acute myeloid leukaemia during colony formation in vitro: a membrane marker analysis with monoclonal antibodies, Br. J. Haematol., 59, 37, 1985.

82. Minden, D., T'ill, J. E., and McCulloch, E. A., Proliferative state of blast cell progenitors in acute myeloblastic leukemia (AML), Blood, 52, 592, 1978.

83. Buick, R. N., Minden, M. D., and McCulloch, E. A., Self renewal in culture of proliferative blast progenitor cells in acute myeloblastic leukemia, Blood, 54, 95, 1979.

84. Chang, L. J. A., Till, J. E., and McCulloch, E. A., The cellular basis of self renewal in culture by human acute myeloblastic leukemic blast cell progenitors, J. Cell Physiol., 102, 217, 1980.

85. Ferrero, D., Pessano, S., Pagliardi, G. L., and Rovera, G., Induction of differentiation of human myeloid leukemias, Blood, 61, $171,1983$.

86. Moore, M. A. S., Williams, N., and Metcalf, D., In vitro colony formation by normal and leukemic human hematopoietic cells: characterization of the colony forming cells, J. Natl. Cancer Inst., 50, 603, 1973.

87. Delwel, R., Touw, I., and Löwenberg, B., Towards detection of minimal disease: discrimination of AML precursors from nomnal myeloid precursors using a combination of surface markers, in Minimal Residual Disease in Acute Leukemia: 1986, Hagenbeek, A. and Löwenberg, B., Eds., Martinus Nijhoff, Dordrecht/Boston, 1986, 68.
88. Löwenberg, B. and Delwel, R., Unfrequent phenotypes of clonogenic cells in AML: evidence for abnormal differentiation and possibilities for detecting minimal disease?, J. Biol. Chem., 1987.

89. Delwel, R., Rugary Bot, F., Touw, I., and Löwenberg, B., Phenotyping of acute myelocytic Leukemia (AML) progenitors: an approach for tracing minimal nucleus of AML cells normal bone marrow, Leukemia, 2, 814, 1989.

90. Young, D. C. and Griffin, J. D., Autocrine secretion of GM-CSF in acute myeloblastic leukemia, Blood, 68, 1178, 1986.

91. Cheng, G. Y. M., Kelleher, C. A., Miyauchi, J., Wang, G., Wong, G., Clark, S. C., McCulloch, E. A., and Minden, M. D., Structure and expression of genes of GM-CSF and G-CSF in blast cells from patients with acute myeloblastic leukemia, Blood, 71, 204, 1988.

92. Young, D. C., Wagner, K., and Grifinn, J. D., Constitutive expression of the granulocyte-macrophage colony stimulating factor gene in acute myeloblastic leukemia, J. Clin. Invest., 79, 100, 1987.

93. Rambaldi, A., Young, D. C., and Grifin, J. D., Expression of the M-CSF (CSF-1) gene by human monocytes, Blood, 69, 1409, 1987.

94. Lee, M., Segal, G. M., and Bagby, G. C., Interleukin-1 induces human bone marrow derived fibroblasts to produce multilineage hematopoietic growth factors, Exp. Hematol., 15, 983, 1987.

95. Zsebo, K. M., Yuschenkoff, V. N., Schiffer, S., Chang, D., McCall, E., Dinarello, C. A., Brown, M. A., Altrock, B., and Bagby, G. C., Vascular endothelial cells and granulopoiesis: interleukin-1 stimulates release of G-CSF and GM-CSF, Blood, 71, 99, 1988.

96. Sieff, C. A., Tsai, S., and Faller, D. V., Interleukin 1 induces cultural human endothelial cell production of granulocyte-macrophage colony stimulating factor, J. Clin. Invest., 79, 48, 1987.

97. Broudy, V., Kanshansky, K., Segal, G., Harlan, J., and Adamson, T. J., Produce granulocyte colony stimulating factor, Proc. Natl. Acad. Sci. U.S.A., 43, 467, 1986.

98. Munker, R., Gasson, J., Ogawa, M., and Koeffler, H. P., Recombinant human TNF induces production of granulocyte-macrophage colony stimulating factor, Nature, 323, 1986

99. Koeffler, H. P., Gasson, J., Ranyard, J., Souza, L., Shepard, M., and Munker, R., Recombinant human TNF $\alpha$ stimulates production of granulocyte colony stimulator factors, Blood, 70, 55, 1987.

100. Fibbe, W. E., van Damme, J., Billiau, A., Voogt, P. J., Duinkerken, N., Klerck, P. M. C., and Falkenburg, J. H. F., Interleukin-1 (22-K factor) induces release of granulocyte-macrophage colonystimulating activity from human mononuclear phagocytes, Blood, 68 , $1316,1986$.

101. Delwel, R., van Buitenen, C., Salem, M., Bot, F., Gillis, S., Kaushansky, K., Altrock, B., and Löwenberg, B., Interleukin-1 stimulates proliferation of acute myeloblastic leukemia cells by induction of endogenous granulocyte-macrophage colony stimulating factor (GMCSF) release, Blood, 74, 586, 1989. 